\title{
EFFECTS OF TWO PROTEASE INHIBITORS ON LARVAE OF ARGENTINE STEM WEEVIL AND CLOVER ROOT WEEVIL
}

\author{
J.H. TODD ${ }^{1}$, L.A. MALONE ${ }^{1}$, H.S. GATEHOUSE ${ }^{2}$, E.P.J. BURGESS ${ }^{1}$, \\ J.T. CHRISTELLER ${ }^{2}$, B.A. PHILIP ${ }^{1}$ and E.L. TREGIDGA ${ }^{1}$
}

${ }^{1}$ HortResearch, Private Bag 92169, Auckland, New Zealand ${ }^{2}$ HortResearch, Private Bag 11030, Palmerston North, New Zealand

Corresponding author: jtodd@hortresearch.co.nz

\begin{abstract}
Protease inhibitors (PIs) cause mortality in a range of insects, and transgenic plants expressing PIs have been protected against pest attack. The effects of feeding two purified PIs to larvae of Argentine stem weevil (Listronotus bonariensis) and clover root weevil (Sitona lepidus) were investigated in laboratory bioassays. The serine PI, aprotinin, and the cysteine PI, E64, were administered continuously in artificial diets to neonate or one-week-old larvae. Aprotinin had no effect on clover root weevil larvae, but significantly inhibited growth of Argentine stem weevil larvae. E64 caused significant mortality in clover root weevil larvae and significant reductions in growth of Argentine stem weevil larvae.

Keywords: Argentine stem weevil, Listronotus bonariensis, clover root weevil, Sitona lepidus, protease inhibitors.
\end{abstract}

\section{INTRODUCTION}

Clover root weevil, Sitona lepidus (Gyllenhal) and Argentine stem weevil, Listronotus bonariensis (Kuschel), (both Coleoptera: Curculionidae), are serious pasture pests in New Zealand (Willoughby et al. 1998; Prestidge et al. 1991). Clover root weevil (CRW) larvae feed on roots and nodules of clovers (Murray \& Clements 1995), and Argentine stem weevil (ASW) larvae feed within vegetative and flowering tillers of grasses (Goldson et al. 2000). It is possible that control of the larval stages of these pests could be achieved by producing plant cultivars that express insect control proteins such as protease inhibitors (PIs).

Several PIs have been investigated for control of insect pests, and some plant species have been transformed to express these PIs to protect them from insect attack (for a review see Michaud 2000). Depending on the gene promoter used and the plant chosen, the PI may be expressed in a range of tissues including roots and foliage (Schuler et al. 1998). Success against weevils has already been achieved with transformed plants protected through the expression of PIs. For example, transgenic strawberry plants were protected from attack by Otiorhynchus sulcatus F. in glasshouse trials (Graham et al. 1997).

Selection of an appropriate PI for production of a resistant plant cultivar requires investigation of the protease activity in the midgut of the pest insect, and in vivo bioassays to determine which PI is the most effective inhibitor of the active proteases (Burgess \& Gatehouse 1997). In vitro and in vivo studies of protease activity in weevils have shown the presence of cysteine, serine and aspartic proteases, with differences in the dominant protease between species (eg. Wilhite et al. 2000; Ortego et al. 1998; Bonade-Bottino et al. 1999; Liang et al. 1991). Consequently, these studies have also found that the effectiveness of different PIs varies between species, thus demonstrating the need to investigate each species individually.

In this study we used in vivo bioassays involving E64 (trans-Epoxysuccinyl-LLeucylamido(4-Guanidino)-Butane, a cysteine PI) and aprotinin (or bovine pancreatic trypsin inhibitor, a serine PI) to examine the potential of these PIs for controlling ASW and CRW. 
Protease Inhibitors

\section{MATERIALS AND METHODS}

Aprotinin was obtained from Intergen Company, Purchase, NY 10577, Lot No NT59808 and WT64111. E64 was obtained from Sigma-Aldrich Co., Lot No. 77H0328 and $77 \mathrm{H} 0321$.

Artificial diets were made which contained $768 \mu \mathrm{M}$ of either aprotinin (equivalent to $0.5 \% \mathrm{w}: \mathrm{w}$ of diet or $13 \%$ of total protein) or E64 (equivalent to $0.0274 \% \mathrm{w}: \mathrm{w}$ of diet or $0.7 \%$ of total protein). The w:w concentration of E64 was much lower than that of aprotinin because it is a much smaller molecule. The $768 \mu \mathrm{M}$ concentration was chosen because of its effectiveness in reducing insect growth and survival in earlier experiments with serine PIs in artificial diet (McManus \& Burgess 1995; E.P.J. Burgess, unpubl. data). Earlier experiments have also shown that for insect control, PIs must be administered at higher concentrations in artificial diet than they would be expressed in transgenic plants, probably because of differences in protein quality and quantity. For example, negative effects have been observed in insects fed on transgenic plants expressing a PI at 0.4 to 1\% of total protein (McManus et al. 1999). Clover root weevil

CRW adults were maintained in cages on white clover (Trifolium repens L.) foliage. Their eggs were collected and placed on moistened filter paper in Petri dishes and incubated at $25^{\circ} \mathrm{C}$ for hatching. A diet originally developed for rearing Fuller's rose weevil, Naupactus cervinus (Boheman) (G. Clare, pers. comm.), was prepared with and without PI additives, and small blocks of each diet were placed in 96-well microtitre plates. Ten one-week-old larvae were placed individually into wells containing aprotinindiet, while another ten were placed in wells containing E64-diet. A further 20 oneweek-old larvae were placed in wells containing diet without additive as controls, and all wells were sealed with transparent film. Larvae were incubated at $18^{\circ} \mathrm{C}$ with a $16: 8 \mathrm{~h}$ light:dark photoperiod and their survival was scored each weekday. Larvae were moved to fresh diet of the same type 28 days after the experiment commenced. The experiment was replicated three times and was terminated after 56 days.

\section{Argentine stem weevil}

The eggs used in these experiments were laid by field-collected ASW adults maintained in cages on ryegrass (Lolium perenne L.) foliage. The eggs were placed individually onto plugs of diet in $4 \mathrm{ml}$ plastic containers that were then sealed and incubated at $25^{\circ} \mathrm{C}$ with a $16: 8 \mathrm{~h}$ photoperiod.

In the first of two experiments, 20 eggs were placed onto ASW diet (Malone \& Wigley 1990) to which E64 had been added, and 20 eggs were placed onto the same diet without additive (control). Larval survival was recorded three times per week. Surviving larvae were weighed after 14 days and moved to fresh diet of the same type. All larvae were subsequently given fresh diet as required. The experiment was replicated three times and was terminated after 98 days.

In the second experiment, the protein content of the ASW diet was reduced to a level more likely to occur in transgenic plants expressing the PIs. ASW diet has a higher protein content (approximately $3.76 \%$ from casein and wheatgerm) than most plants (approximately 2\%). Consequently, a diet with half the amount of casein and wheatgerm was made, and either E64 or aprotinin was added to it. Twenty five eggs were placed individually on to each of the following four diets: (1) standard ASW diet; (2) reducedprotein ASW diet; (3) reduced-protein ASW diet containing E64; and (4) reduced-protein ASW diet containing aprotinin. Larval survival was recorded three times per week and larvae were weighed 14,21 and 28 days after the study had commenced. The insects were transferred to fresh diet each time they were weighed. On Day 29 larvae which weighed more than $0.001 \mathrm{~g}$ were removed from the experiment, while the remaining larvae were removed on Day 36. The experiment was replicated three times.

Statistical analysis

Log-rank tests were used to compare Kayden-Meir estimates of survival distribution S(t) for each insect (Kalbfleisch \& Prentice 1980). ANOVA and Tukey tests were used to compare ASW weights. 
Clover root weevil larvae

\section{RESULTS}

Larvae feeding on the E64 diet died significantly sooner than those on aprotinin or control diets $(\mathrm{P}<0.001, \log$-rank test) (Fig. 1).

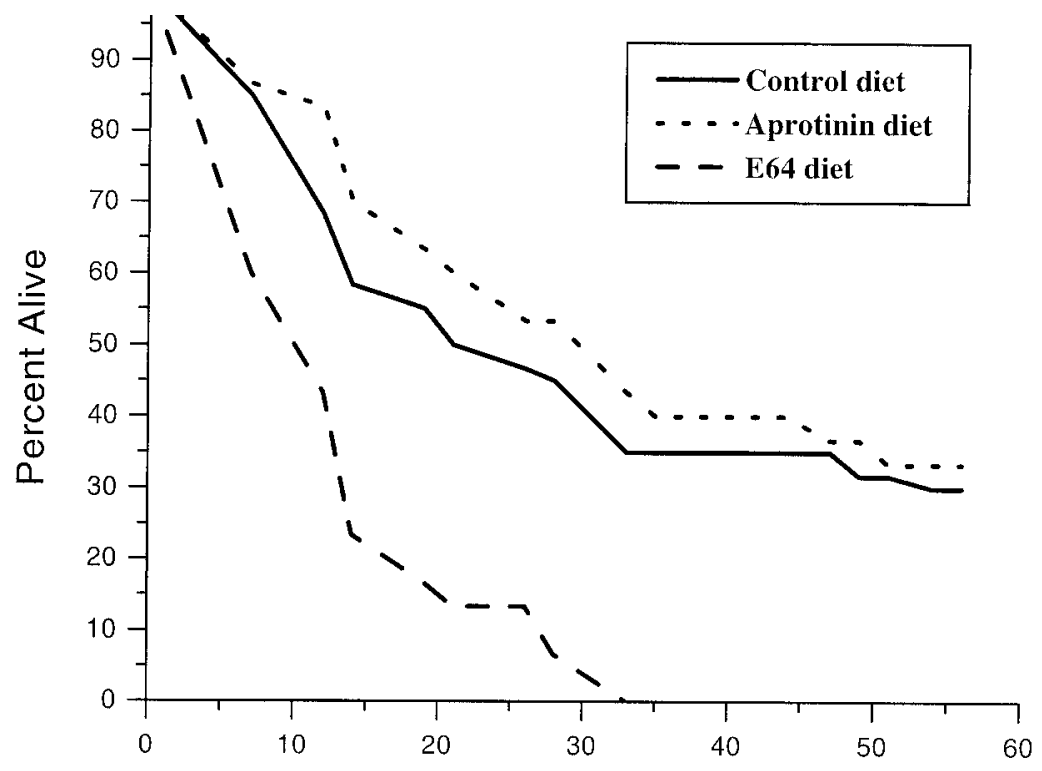

FIGURE 1: Mean survival of CRW larvae placed as one-week-old larvae on artificial diets containing $768 \mu \mathrm{M}(0.5 \%$ w:w) aprotinin or $768 \mu \mathrm{M}$ $(0.0274 \%$ w:w) E64.

\section{Argentine stem weevil larvae}

In the first experiment, larvae fed E64 diet were significantly smaller at Day 14 than those fed control diet $(\mathrm{P}<0.001$, ANOVA). There was no significant difference in minimum survival time.

In the second experiment, larvae fed on diets containing either PI had significantly reduced growth compared with the controls (Fig. 2). The E64 diet had a more marked effect than the aprotinin diet. Both PI diets also had a significant effect on larval survival ( $\mathrm{P}<0.01, \log$-rank test), with 3\%, 0\%, 8\% and $15 \%$ mortality of larvae feeding on standard, low protein, aprotinin and E64 diets respectively.

\section{DISCUSSION}

The bioassays showed that larvae of CRW and ASW are more sensitive to the cysteine PI, E64, than the serine PI, aprotinin. The indication that they use cysteine proteases as their major digestive enzymes was confirmed by preliminary tests which showed that $70 \%$ of total protease activity in extracts from CRW larvae midguts was inhibited by E64 in vitro (H. Gatehouse, pers. comm.). Use of cysteine proteases as major digestive enzymes by CRW and ASW larvae accords with results from several other weevils including Hypera postica Gyllenhal (Wilhite et al. 2000), Baris coerulescens Scop. (Bonade-Bottino et al. 1999) and Otiorynchus sulcatus F. (Michaud et al. 1995). 


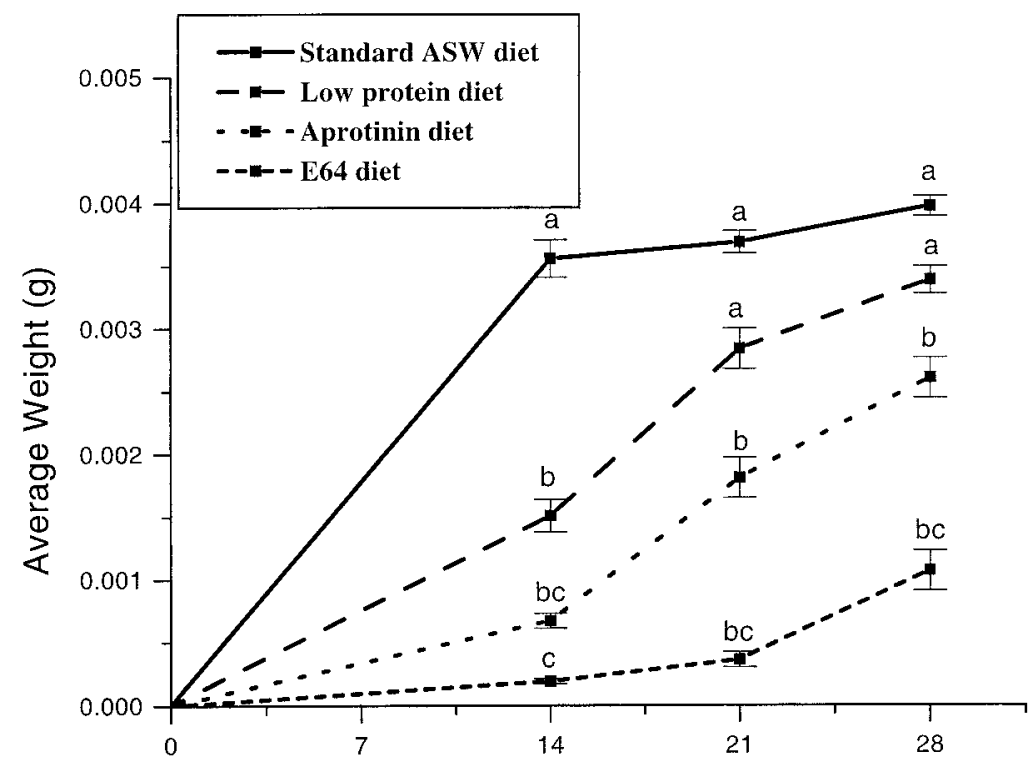

FIGURE 2: Growth of ASW larvae fed on artificial diets containing $768 \mu \mathrm{M}$ $(0.5 \%$ w:w) aprotinin or $768 \mu M(0.0274 \%$ w:w) E64. Data points with the same letter do not differ significantly according to Tukey's LSD $(P=0.0012)$. Error bars show standard error of the mean.

Our results suggested that ASW larvae also use serine proteases because their growth and survival were significantly affected by aprotinin. Studies on other weevils have shown that there can be more than one type of protease present in the midgut (Wilhite et al. 2000; Bonade-Bottino et al. 1999). It is possible that even greater effects on ASW may be obtained with the use of both complementary PIs. Ortego et al. (1998) obtained significantly higher mortality in the weevil Aubeonymus mariaefranciscae (Roudier) using combinations of two or three inhibitors. This possibility should be investigated for control of ASW larvae.

Further information on the action of the PIs on weevil larvae midgut protease activity will be obtained from in vitro analysis of the guts taken from the larvae used in these experiments. This should show whether the activity of serine or cysteine proteases has been altered in larvae that were fed PIs.

It is concluded that CRW and ASW larvae could be controlled by cysteine PIs, such as E64, and ASW may also be controlled by serine PIs. The effects of plants transformed to express PIs on the survival and development of CRW and ASW would need to be tested to confirm this. In addition, it would be important to examine the tritrophic effects of these plants on natural enemies such as the ASW parasitoid, Microctonus hyperodae Loan (Hymenoptera: Braconidae).

\section{ACKNOWLEDGEMENTS}

We thank Dr Anne Gunson of HortResearch for statistical analyses. Our thanks also to Graham Clare of HortResearch for providing the recipe for Fuller's rose weevil diet. Funding was provided by the NZ Foundation for Research, Science and Technology. 


\section{REFERENCES}

Bonade-Bottino, M.; Lerin, J.; Zaccomer, B.; Jouanin, L. 1999: Physiological adaptation explains the insensitivity of Baris coerulescens to transgenic oilseed rape expressing oryzacystatin I. Insect Biochem. Molec. Biol. 29: 131-138.

Burgess, E.P.J.; Gatehouse, A.M.R. 1997: Engineering for insect pest resistance. In: McKersie, B.D.; Brown, D.C.W. ed. Biotechnology and the Improvement of Forage Legumes. CAB International, Wallingford, U.K. Pp. 229-258.

Goldson, S.L.; Proffitt, J.R.; Fletcher, L.R.; Baird, D.B. 2000: Multitrophic interaction between the ryegrass Lolium perenne, its endophyte Neotyphodium lolii, the weevil pest Listronotus bonariensis, and its parasitoid Microctonus hyperodae. N.Z. J. Agric. Res. 43: 227-233.

Graham, J.; Gordon, S.C.; McNicol, R.J. 1997: The effect of the CpTi gene in strawberry against attack by vine weevil (Otiorhynchus sulcatus F. Coleoptera: Curculionidae). Ann. Appl. Biol. 131: 133-139.

Kalbfleisch, J.D.; Prentice, R.L. 1980: Statistical Analysis of Failure-Time Data. John Wiley, New York, USA.

Liang, C.; Brookhart, G.; Feng, G.H.; Reeck, G.R.; Kramer, K.J. 1991: Inhibition of digestive proteinases of stored grain coleoptera by oryzacystatin, a cysteine proteinase inhibitor from rice seed. FEBS Letters 278: 139-142.

Malone, L.A.; Wigley, P.J. 1990: A practical method for rearing Argentine stem weevil, Listronotus bonariensis (Coleoptera: Curculionidae) in the laboratory. N.Z. Entomol. 13: 87-88.

McManus, M.T.; Burgess, E.P.J. 1995: Effects of the soybean (Kunitz) trypsin inhibitor on growth and digestive proteases of larvae of Spodoptera litura. J. Insect Physiol. 41: 731-738.

McManus, M.T.; Burgess, E.P.J.; Philip, B.; Watson, L.M.; Laing, W.A.; Voisey, C.R.; White, D.W.R. 1999: Expression of the soybean (Kunitz) trypsin inhibitor in transgenic tobacco: Effects on larval development of Spodoptera litura. Transgenic Res. 8: 383-395.

Michaud, D. (ed) 2000: Recombinant Protease Inhibitors in Plants. Biotechnology Intelligence Unit 3, Eurekah.com, Texas, USA.

Michaud, D.; Cantin, L.; Vrain, T.C. 1995: Carboxy-terminal truncation of oryzacystatin II by oryzacystatin-insensitive insect digestive proteinases. Arch. Biochem. Biophys. 322: 469-474.

Murray, P.J.; Clements, R.O. 1995: Distribution and abundance of three species of Sitona (Coleoptera: Curculionidae) in grassland in England. Ann. Appl. Biol. 127: 229237.

Ortego, F.; Farinos, G.P.; Ruiz, M.; Marco, V.; Castanera, P. 1998: Characterization of digestive proteases in the weevil Aubeonymus mariaefranciscae and effects of proteinase inhibitors on larval development and survival. Entomol. Exp. Appl. 88: 265-274.

Prestidge, R.A.; Barker, G.M.; Pottinger, R.P. 1991: The economic cost of Argentine Stem weevil in pastures in New Zealand. Proc. $44^{\text {th }}$ N.Z. Weed and Pest Control Conf.: 165-170.

Schuler, T.H.; Poppy, G.M.; Kerry, B.R.; Denholm, I. 1998: Insect-resistant transgenic plants. Trends Biotechnol. 16: 168-175.

Willoughby, B.; Addison, P.; Baker, M. 1998: Clover root weevil (Sitona lepidus) - a threat to the sustainability of white clover in New Zealand pastures? Proc. N.Z. Grassland Assoc. 59: 23-27.

Wilhite, S.E.; Elden, T.C.; Brzin, J.; Smigocki, A.C. 2000: Inhibition of cysteine and aspartyl proteinases in the alfalfa weevil midgut with biochemical and plant-derived proteinase inhibitors. Insect Biochem. Molec. Biol. 30: 1181-1188. 